\title{
Foramen Magnum Dural Arteriovenous Fistula Treated by a Microsurgical Technique Combined with a Feeder Occlusion Using Transarterial Coil Embolization
}

\author{
Mikrocerrabi Teknik ve Transarteriyel Koil Embolizasyonu Yoluyla \\ Besleyici Damar Oklüzyonu ile Kombine Olarak Tedavi Edilen \\ Foramen Magnum Dural Arteriovenöz Fistülii
}

Ryo HIRAMATSU ${ }^{1}$, Terumasa KUROIWA ${ }^{1}$, Kazuhiko NOZAKI², Toshihiko KUROIWA ${ }^{3}$

${ }_{1}^{1}$ Shimizu Hospital, Department of Neurosurgery, 11-2 Yoshimi-Cho, Yamada, Nishikyo-Ku, Kyoto, Japan

${ }^{2}$ Shiga University of Medical Science, Department of Neurosurgery, Seta Tukinowa-Cho, Otsu City, Shiga, Japan

${ }^{3}$ Osaka Medical College, Department of Neurosurgery, 2-7 Daigaku-Machi, Takatsuki City, Osaka, Japan

Corresponding Author: Ryo HIRAMATSU / E-mail: neu106@poh.osaka-med.ac.jp

\begin{abstract}
The treatment of dural arteriovenous fistulas (DAVFs) at the foramen magnum remains controversial by reason that DAVFs appearing from the foramen magnum represent only a minority of spinal DAVFs. We present our treatment for an asymptomatic patient suffering from a foramen magnum DAVF. A 53-year-old man presented to our hospital with the complaint of a floating sensation. Although there was no subarachnoid hemorrhage or cerebral infarction on magnetic resonance imaging, a magnetic resonance angiography revealed a number of dilated veins and a large varix surrounding the medulla oblongata. Cerebral digital subtraction angiography (DSA) showed a foramen magnum DAVF fed by the neuromeningeal branch of the left ascending pharyngeal artery and occipital artery, draining into the posterior spinal vein. Occlusion of the fistula was achieved by a microsurgical technique combined with a feeder occlusion using transarterial coil embolization, without complications. We verified the complete occlusion on post-operative cerebral DSA. While this combined therapy was already established for the treatment of DAVFs, there were no reports of the combined therapy for foramen magnum DAVFs. This treatment was considered to be useful for foramen magnum DAVFs, especially those DAVFs at the foramen magnum with a number of dilated veins and a large varix.
\end{abstract}

KEYWORDS: Ascending pharyngeal artery, Combination therapy, Dural arteriovenous fistula, Foramen magnum, Transarterial coil embolization

öz

Foramen magnum'daki dural arteriovenöz fistüllerin (DAVF) tedavisi spinal DAVF'in çok azı foramen magnumda yerleştiği için tartışmalıdır. Makalede asemptomatik bir hastada tesbit edilen foramen magnum DAVF'ünde uyguladığımız tedaviyi sunuyoruz. 53 yaşında erkek hasta hastanemize duyularında dalgalanma şikayeti ile başvurdu. Hastanın manyetik rezonans incelemesinde subaraknoid kanama veya serebral enfarkt olmamakla birlikte manyetik rezonans anjiyografi medulla oblongata çevresinde çok sayıda genişlemiş ven ve bir adet büyük bir varis olduğunu gösterdi. Serebral dijital subtraksiyon anjiyografi (DSA) sol asendan farengeal arterin nöromeningeal dalından ve oksipital arterden beslenen, posterior spinal vene drene olan bir foramen magnum DAVF'nü gösterdi. Fistülün oklüzyonu mikrocerrahi teknikle kombine olarak uygulanan besleyici damarın transarteriyal koil ile embolizasyonu yoluyla komplikasyonsuz olarak sağlandı. Postoperatif serebral DSA ile tam oklüzyonu doğruladık. DAVF'ler için kombine tedavi daha önce tanımlanmış olmakla birlikte, foramen magnumda yerleşmiş DAVF'ler bu yöntem hiç yayınlanmamıştır. Bu tedavi yöntemi foramen magnum DAVF'leri için, özellikle çok sayıda dilate ven ve geniş varisi olan olgularda, oldukça kullanışlıdır.

ANAHTAR SÖZCÜKLER: Asendan farengeal arter, Kombine tedavi, Dural arteriovenöz fistül, Foramen magnum, Transarteriyal koil embolizasyonu

\section{INTRODUCTION}

Spinal dural arteriovenous fistulas (DAVFs) may appear at any level from the foramen magnum to the sacrum, but are most generally found at the thoracic vertebra and the lumbar vertebra. Patients characteristically present with slowly progressive myelopathy with spastic or flaccid paraparesis and vesicorectal disturbances, which result from venous hypertension in the medullary veins $(6,10)$. DAVFs appearing from the foramen magnum represent only a minority of spinal DAVFs $(3,7,9,11)$, but in contrast to DAVFs at the thoracic vertebra and the lumbar vertebra, they may be associated with other clinical manifestations such as a subarachnoid 
hemorrhage $(\mathrm{SAH})$. To achieve the obliteration of a foramen magnum DAVF, the shunt site may be targeted by microsurgical clipping $(1,2,7,8,11)$ or by neuroendovascular therapy $(3,4)$. It is not known which method of obliteration is more effective.

We recently treated an asymptomatic patient with a foramen magnum DAVF, and we were able to achieve occlusion of the fistula by a microsurgical technique combined with a feeder occlusion using transarterial coil embolization, without complications. We report the usefulness of this combination therapy for DAVF at the foramen magnum, especially cases of DAVF at the foramen magnum with a number of dilated veins and a large varix.

\section{CASE REPORT}

A 53-year-old Japanese man presented at our hospital with a floating sensation in December 2013. Although there was no $\mathrm{SAH}$ or cerebral infarction on magnetic resonance imaging (MRI), a magnetic resonance angiography (MRA) revealed a number of dilated veins and a large varix surrounding the medulla oblongata (Figure $1 \mathrm{~A}$ ). In order to receive a further examination, he was admitted to our hospital. On the day following his admission, he experienced a complete improvement of his symptom without treatment. However, on computed tomography (CT) angiography, a number of dilated veins and a large varix at the foramen magnum were observed at the level of the hypoglossal canal (Figure 1B). Pre-operative cerebral digital subtraction angiography (DSA) indicated a foramen magnum DAVF fed by the neuromeningeal branch of the left ascending pharyngeal artery (APA) and occipital artery $(O A)$ (Figure 2A, B), draining into the posterior spinal vein (Figures $2 \mathrm{C}, \mathrm{D}$ ).

Pre-operative images showed that the patient had a number of dilated veins and a large varix at the caudal end of a shunt point and we performed transarterial coil embolization of the left APA and the OA for the flow reduction of a number of dilated veins and the large varix. CT after the coil embolization showed the coil in the hypoglossal canal near the shunt point (Figure 3A). Flow reduction of the dilated veins and a large varix was achieved by transarterial coil embolization, as shown by MRA (Figures 3B, C). Three days after the coil embolization, we used a microsurgical technique with the patient in the prone position. A paramedian dural mater incision was performed, following left-sided enlargement of the foramen magnum decompression and partial hemilaminectomy of $\mathrm{C} 1$. After the dissection of the arachnoid membrane, a number of dilated veins and a large varix were revealed (Figure 4A). Beyond these vessels, a tortuous vessel was identified with an arterial flow-pattern by intraoperative indocyanine green videoangiography (ICG-VA) (Figure 4B). We achieved occlusion of this vessel near the dural entry zone beyond a number of dilated veins and the large varix, using a 7-mm straight clip (Figure 4C) with verification of complete occlusion of the fistula by intraoperative ICG-VA (Figure 4D).

The disappearance of the shunt was shown on post-operative cerebral DSA (Figures 2E-F), and the patient was discharged at 13 days after the surgery using the microsurgical technique, with the modified Rankin Scale score of 0 (Figure 1C).

\section{DISCUSSION}

Although the treatment of a foramen magnum DAVF remains controversial $(3,7,11)$, direct microsurgery has been the predominant choice. In a few reported cases, arterial embolization treatments have been used $(3,4)$, and in one report, the treatment of the intravascular embolization was incomplete and direct microsurgery was required for definitive ligation (11). The anastomosis of the meningeal artery supply around the foramen magnum indicates that treatment by direct microsurgery of the arterialized venous

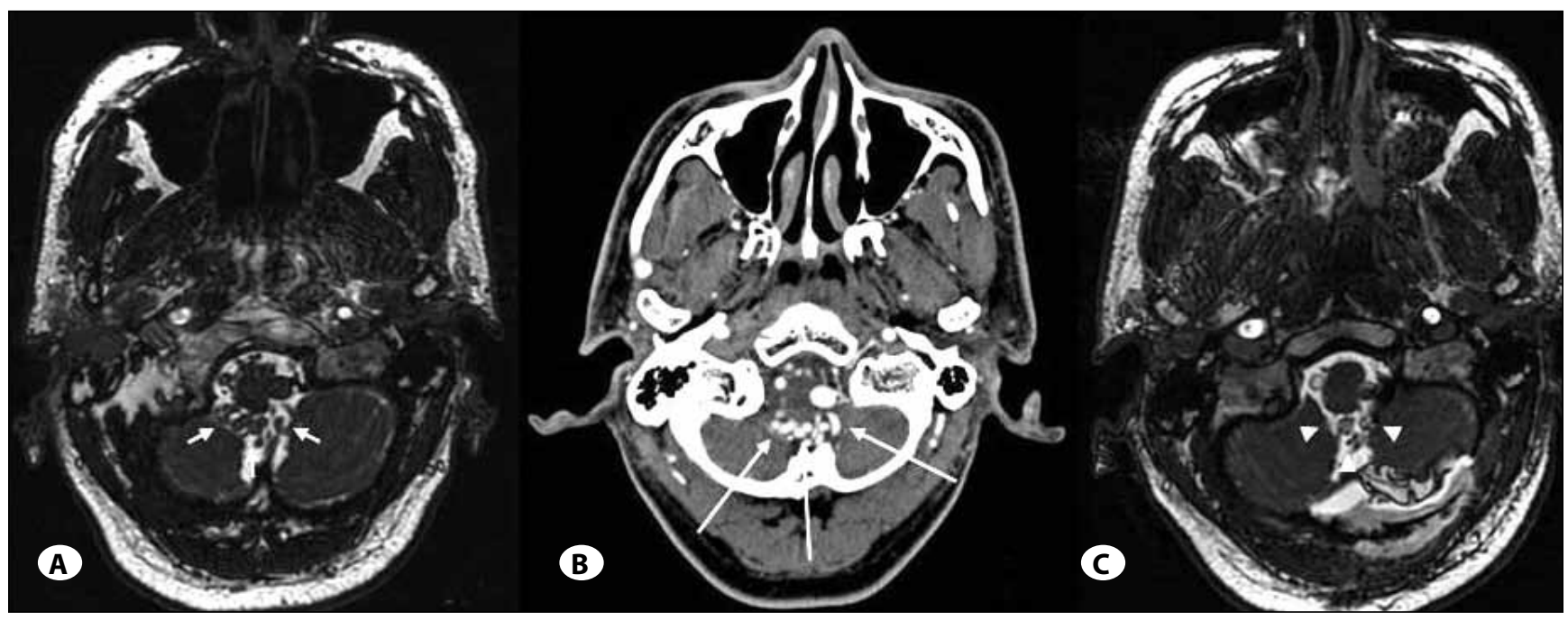

Figure 1: A) Pre-operative MRI revealed a number of dilated veins and a large varix surrounding the medulla oblongata (short white arrows). B) A foramen magnum DAVF was observed at the level of the hypoglossal canal (long white arrows). C) Post-operative MRI revealed the shrinkage of dilated veins and the varix (white arrowheads). 

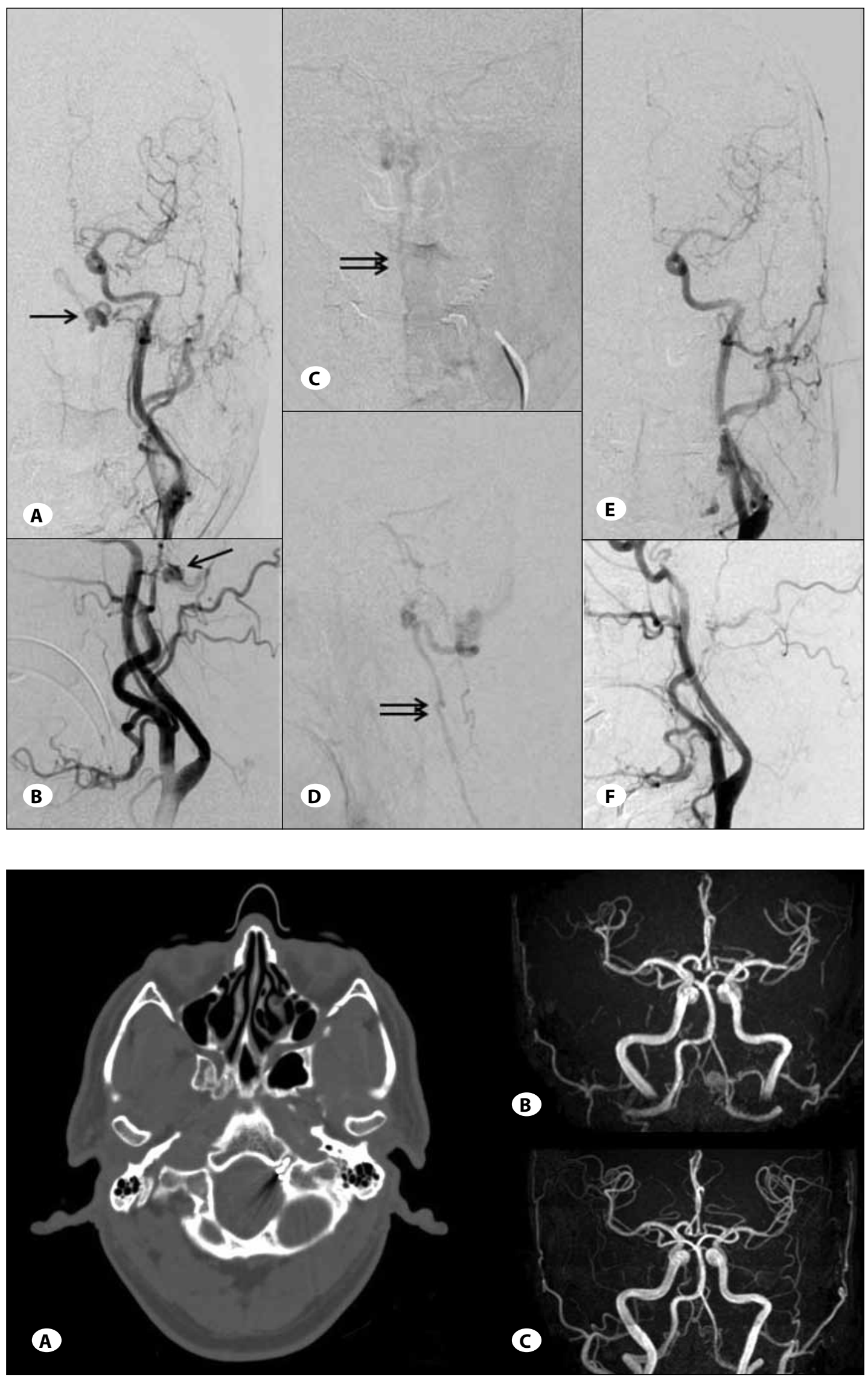

Figure 2:

A-D) The DAVF with a large varix (single black arrows,

A, B) was fed by the neuromeningeal branch of the APA and the $O A$, and it drained into the posterior spinal vein (double black arrows, C, D).

E, F) Postoperative cerebral DSA showed the complete disappearance of the DAVF.

Figure 3:

A) CT after the coil embolization showed a coil mass in the hypoglossal canal.

B) MR angiography (MRA) before the coil embolization showed the dilated veins and a large varix.

C) MRA after the coil embolization suggested the flow reduction in the dilated veins and large varix. 


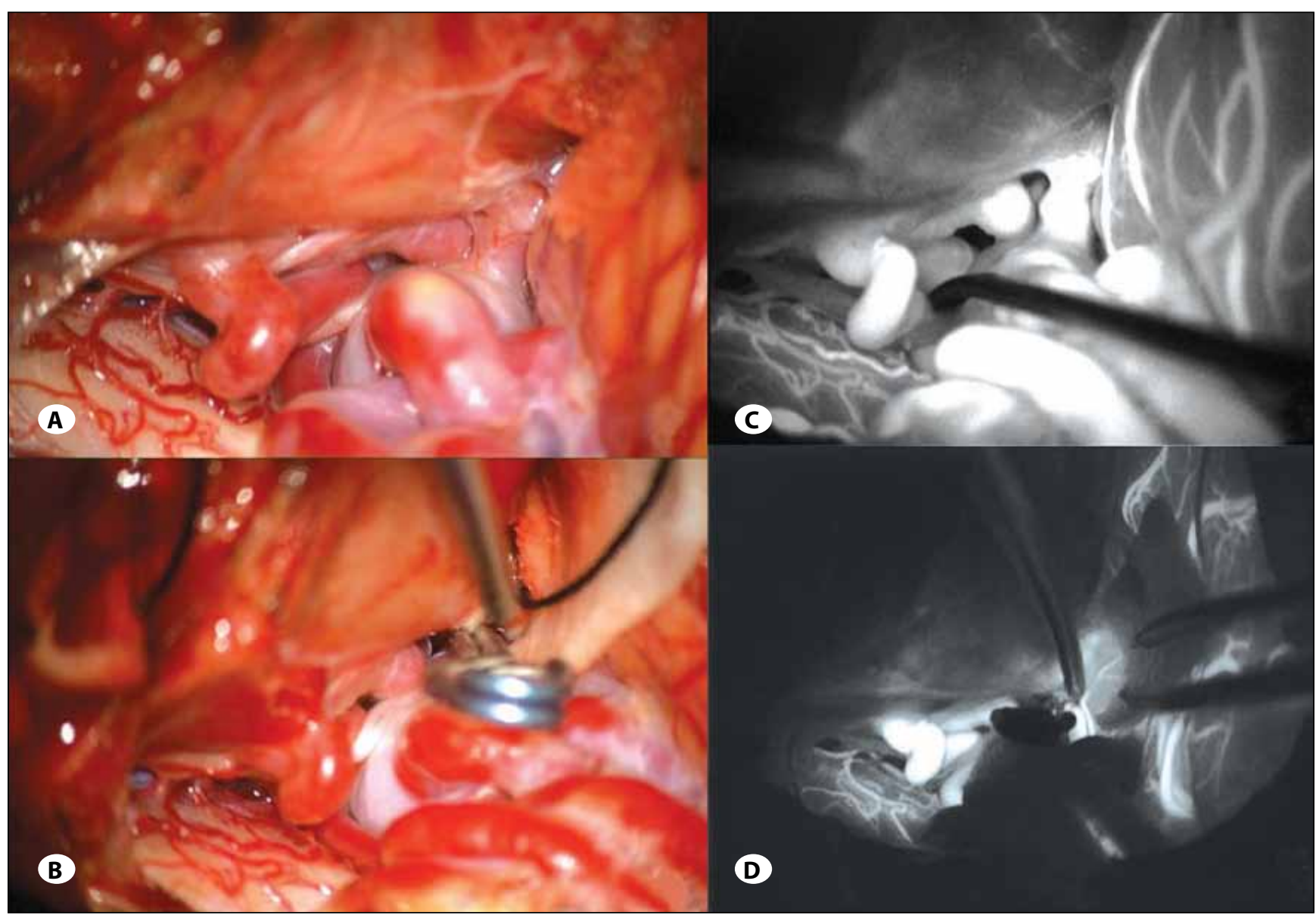

Figure 4: A) After the dissection of the arachnoidea, dilated veins and a large varix were revealed. B) Intraoperative ICG-VA showed dilated veins and a varix at the arterial phase. C) Occlusion of a shunt point was performed using a 7-mm straight clip. D) Intraoperative ICG-VA verified the disappearance of DAVF.

circulation may be preferable to arterial embolization $(7,11)$. The disadvantages of an intravascular embolization when compared with a direct microsurgery are as follows: (A) it has a risk of infarction by occlusion of normal vessels (3); (B) it has the difficulty of introducing a microcatheter into the fine arteries feeding the DAVF; and (C) recanalization can occur after the embolization, especially using particles. (11). However, intravascular embolization is an increasingly effective therapy for the treatment of spinal DAVFs, and the newer embolic agents, such as Onyx (4), hold significant promise for future therapy, although long-term follow-up studies are required $(5,10)$.

In our case, there were a number of dilated veins and a large varix at the caudal end of a shunt point. Difficulty detecting a shunt point was thus expected when we performed a surgery using the suboccipital approach. In order to reduce the blood flow into the patient's dilated veins and varix, we performed a feeder occlusion using transarterial coil embolization ahead of the microsurgical technique. This procedural precaution was used to avoid causing a cranial nerve injury, especially a lower cranial nerve injury feeding the neuromeningeal branch of APA. We therefore decided to use the coil without glue and made an effort to pass a microcatheter close to a shunt point during this procedure. The CT after the feeder occlusion using the transarterial coil embolization showed the coil in the hypoglossal canal near the shunt point (Figure 3A). In a microsurgical technique, the shunt point can be detected using a suboccipital approach, not using a transcondylar approach.

\section{CONCLUSION}

In the present case we successfully achieved devascularization of a shunt point at the foramen magnum through a combination therapy, without any complications. In Japan at present, the Pharmaceutical Affairs Act limits the use of Onyx to pre-operative applications for arteriovenous malformations. In this context, a feeder occlusion using the transarterial coil embolization ahead of a microsurgical technique is considered acceptable and useful. 


\section{REFERENCES}

1. Gilard V, Curey S, Tollard E, Proust F: Coincidental vascular anomalies at the foramen magnum: Dural arteriovenous fistula and high flow aneurysm on perimedullary fistula. Neurochirurgie 59:210-213, 2013

2. Guo LM, Zhou HY, Xu JW, Wang GS, Tian X, Wang Y, Qiu YM, Jiang JY: Dural arteriovenous fistula at the foramen magnum presenting with subarachnoid hemorrhage: Case reports and literature review. Eur J Neurol 17:684-691, 2010

3. Kim MS, Han DH, Han MH, Oh CW: Posterior fossa hemorrhage caused by dural arteriovenous fistula: Case reports. Surg Neurol 59:512-516; discussion 516-517, 2003

4. Liang G, Gao X, Li Z, Wang X, Zhang H, Wu Z: Endovascular treatment for dural arteriovenous fistula at the foramen magnum: Report of five consecutive patients and experience with balloon-augmented transarterial Onyx injection. J Neuroradiol 40:134-139, 2013

5. Medel R, Crowley RW, Dumont AS: Endovascular management of spinal vascular malformations: History and literature review. Neurosurg Focus 26:E7, 2009

6. Narvid J, Hetts SW, Larsen D, Neuhaus J, Singh TP, McSwain H, Lawton MT, Dowd CF, Higashida RT, Halbach VV: Spinal dural arteriovenous fistulae: Clinical features and long-term results. Neurosurgery 62:159-166, discussion 166-157, 2008
7. Reinges $M H$, Thron A, Mull M, Huffmann BC, Gilsbach JM: Dural arteriovenous fistulae at the foramen magnum. J Neurol 248:197-203, 2001

8. Renner C, Helm J, Roth $\mathrm{H}$, Meixensberger J: Intracranial dural arteriovenous fistula associated with progressive cervical myelopathy and normal venous drainage of the thoracolumbar cord: Case report and review of the literature. Surg Neurol 65:506-510, 2006

9. Rivierez M, Gazengel J, Chiras J, Dorwling-Carter D, Debussche D, Dubbs M, Kanaan H: Vertebro-dural arteriovenous fistulae of the foramen magnum with perimedullary venous drainage. Neurochirurgie 37:179-184, 1991

10. Sivakumar W, Zada G, Yashar P, Giannotta SL, Teitelbaum G, Larsen DW: Endovascular management of spinal dural arteriovenous fistulas. A review. Neurosurg Focus 26:E15, 2009

11. Takami T, Ohata K, Nishio A, Nishikawa M, Goto T, Tsuyuguchi $\mathrm{N}$, Hara M: Microsurgical interruption of dural arteriovenous fistula at the foramen magnum. J Clin Neurosci 12:580-583, 2005 